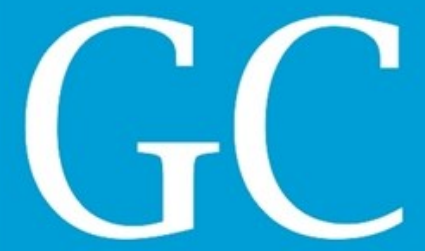

Revista Nacional de Gerenciamento de Cidades National Journal of Cities Management

\title{
Projeto Urbano e Espaço Público em Favelas
}

Urban Project and Public Space in Favelas

Diseño urbano y espacio público en los barrios pobres

Wagner de Souza Rezende

Doutorando pela PPGAU/FAU Mackenzie, Bolsista Taxa Prosup/Capes Docente do Curso de Arquitetura e Urbanismo da UFG wagnerrezende@hotmail.com

\section{Angélica T. Benatti Alvim} Docente do PPGAU/FAU Mackenzie Bolsista Produtividade CNPq nível 2 angelica.benatti.alvim@gmail.com 


\section{RESUMO}

Este trabalho aborda o papel dos projetos urbanos na "ativação" de espaços públicos em favelas. Pretende-se, assim, analisar dialeticamente os elementos-chave que caracterizam as intervenções urbanas em contextos de precariedade, no sentido de indicar as condições que favorecem a apropriação dos espaços públicos resultantes. De um lado, os projetos urbanos podem ser entendidos como mediadores de relações sociais cotidianas, indo além de soluções normativas, valorizando as identidades locais e as pré-existências. De outro lado, podem-se interpretar determinados projetos urbanos em territórios informais como instrumentos de "formalização" socioespacial. É possível que essa estratégia atue a serviço de uma ideologia neoliberal, de ordem distante, orientada para monopolizar o direito à cidade e gerar instabilidades identitárias no território. De modo paradoxal, pode-se argumentar que certos projetos urbanos em favelas atuam como obstáculos a possíveis mediações dos moradores no espaço público. Em oposição, o ativismo urbano tem sido apresentado como um conjunto de estratégias e táticas fundamentadas na participação popular inclusiva em todas as etapas de produção do espaço público. Para uma crítica das relações entre projeto urbano, espaço público e lugar, propõe-se a análise de dois projetos urbanos - não construídos - em Paraisópolis, com foco em quatro componentes, o discurso do projeto, o respeito às pré-existências, a participação popular democrática e inclusiva e o atendimento às necessidades locais. Em um momento no qual se discutem planos de desenvolvimento estratégico pautados por políticas públicas frágeis, pretende-se, assim, discutir o papel de projetos urbanos na melhoria da qualidade do espaço público em favelas.

Palavras-chave: Projeto Participativo, Espaço Público, Lugar, Favela, Paraisópolis.

\section{SUMMARY}

This paper discusses the role of urban projects in the "activation" of public spaces in favelas. It is intended, therefore, to analyze the key elements that characterize urban interventions in contexts of precariousness, in order to indicate the conditions that favor the appropriation of the resulting public spaces. On the one hand, urban projects can be understood as mediators of everyday social relations, going beyond normative solutions, valuing local identities and pre-existences. On the other hand, certain urban projects can be interpreted in informal territories as instruments of "formalization" sociospatial. It is possible that this strategy acts at the service of a neoliberal ideology, of distant order, oriented to monopolize the right to the city and to generate identity instabilities in the territory. In a paradoxical way, it can be argued that certain urban projects in favelas act as obstacles to the possible mediations of the residents in the public space. In opposition, urban activism has been presented as a set of strategies and tactics based on inclusive popular participation in all stages of public space production. For a critique of the relationships between urban design, public space and place, it is proposed the analysis of two urban projects - not built - in Paraisópolis, focusing on four components: project discourse, respect for pre-existences, participation Democratic and inclusive population and meeting local needs. At a time when discussing strategic development plans based on fragile public policies, it is intended to discuss the role of urban projects in improving the quality of public space in favelas.

Keywords: Participative Project, Public Space, Place, Favela, Paraisópolis.

\section{RESUMEN}

Este documento aborda el papel del diseño urbano en la "activación" de los espacios públicos en los barrios pobres. El objetivo es analizar dialécticamente por lo tanto los elementos clave que caracterizan las intervenciones urbanas en contextos precarios, para indicar las condiciones que favorecen la apropiación de los espacios públicos resultantes. Por un lado, los proyectos urbanos pueden ser entendidos como mediadores de las relaciones sociales cotidianas, más allá de las soluciones reguladoras, la mejora de las identidades locales y preexistencias. Por otro lado, se puede interpretar ciertos proyectos urbanos en áreas informales como instrumentos de socioespacial "formalización". Es posible que esta estrategia funciona al servicio de una ideología neoliberal, el orden lejano, orientado a monopolizar el derecho a la ciudad y generar inestabilidades de identidad en el territorio. Paradójicamente, se puede argumentar que ciertos proyectos urbanos en los barrios pobres actúan como obstáculos para posibles mediaciones de los residentes en el espacio público. Por el contrario, el activismo urbano ha sido presentado como un conjunto de estrategias y tácticas basadas en la participación inclusiva popular en todas las etapas de producción del espacio público. Para una crítica de la relación entre el diseño urbano, el espacio público y el lugar, se propone el análisis de dos proyectos urbanos - no - construidos en Paraisópolis, centrándose en cuatro componentes, el proyecto de expresión, el respeto de preexistente, la participación democrático e inclusivo popular y satisfacer las necesidades locales. En un momento en el que se discuten los planes estratégicos de desarrollo guiados por las políticas públicas débiles, se pretende, por lo tanto, para discutir el papel del diseño urbano en la mejora de la calidad del espacio público en los barrios pobres.

Palabras clave: diseño participativo, el espacio público, el lugar, Favela, Paraisópolis. 


\section{INTRODUÇÃO}

Este trabalho aborda o papel dos projetos urbanos na produção de espaço público em favelas, sob a perspectiva de processos participativos de decisão. O objetivo desse trabalho é descrever e analisar, dialeticamente, as implicações entre projetos urbanos e espaços públicos em assentamentos precários, especialmente em favelas localizadas nas regiões metropolitanas.

Nesse sentido, a discussão se orientará no campo do desenvolvimento local, na perspectiva multiescalar das apropriações dos espaços públicos como possibilidades dos projetos urbanos, no nível discursivo e da realidade concreta. A partir de duas perspectivas antagônicas, pretende-se identificar os elementos-chave que caracterizam as intervenções urbanas em contextos de precariedade, no sentido de indicar as condições que favorecem a apropriação dos espaços públicos resultantes.

Para uma crítica das relações entre projeto urbano, urbanidade e identidade, propõe-se a análise de dois projetos urbanos, não construídos, propostos para a favela de Paraisópolis( SP), com foco em quatro componentes: 1) o discurso do projeto, 2) o respeito às preexistências, 3 ) a participação popular, e ,4) o atendimento às necessidades locais. 0 primeiro projeto é o Conjunto Habitacional, de autoria do escritório chileno Elemental, que seria construído em terreno localizado às margens da Avenida Hebe Camargo, implantada em área urbanizada pela prefeitura de São Paulo entre 2008 e 2010. O segundo projeto é a Escola de Música - também conhecida como centro de infraestrutura cívica e de recuperação urbana - de autoria do grupo venezuelano Urban Think Tank.

Com uma área de aproximadamente 100 hectares de propriedade particular e uma população de aproximadamente 80.000 habitantes, Paraisópolis tem sua origem na ocupação de um loteamento planejado e implantado em 1921, que definiu aproximadamente dois mil e duzentos lotes implantados em malha viária ortogonal, composta por quadras regulares de $100 \mathrm{~m} \times 200 \mathrm{~m}$ em vias com $10 \mathrm{~m}$ de largura. Considerada a segunda maior favela do município de São Paulo, encontra-se implantada em terreno de relevo acidentado, incluindo vales alagáveis e regiões de alta declividade, onde se localizam atualmente as grotas. Essa topografia específica, natural da região do Morumbi, dificultou muito a ocupação imediata pelos proprietários e o consequente abandono por décadas. A abrangência atual do complexo inclui as comunidades Paraisópolis, Jardim Colombo e Porto Seguro. O território encontra-se hoje sob a jurisdição administrativa das Subprefeituras de Campo Limpo e Butantã.

\section{OBJETO, QUESTÃO FUNDAMENTAL E HIPÓTESE}

O objeto dessa pesquisa é o espaço público, ou melhor, os modos de apropriação do espaço público. A questão fundamental: qual o papel dos projetos urbanos na produção de espaços públicos? A hipótese dessa pesquisa é de que a adoção de estratégias orientadas para a implantação de estruturas essenciais para a apropriação do espaço público, articuladas com táticas cotidianas de apropriação desses espaços pelos moradores locais, pode contribuir para a melhoria da qualidade de vida e o desenvolvimento local. 


\title{
CONCEITOS: ESPAÇO PÚBLICO, PROJETO URBANO E LUGAR.
}

\author{
ESPAÇO PÚBLICO
}

Nesse ponto do texto talvez seja pertinente não apenas delimitar o que seja espaço público, mas, antes, explicitar as relações entre cidade, urbanismo e espaço público. Lefebvre (2001) nos ensina que a cidade pode ser comparada a uma obra de arte, uma realidade concreta, resultado de uma sucessão regulamentada de ações, decisões, condutas, mensagens e códigos, que atuam sobre um meio específico. Em suas palavras, "se a realidade social implica formas e relações, se ela não pode ser concebida de maneira homóloga ao objeto isolado, sensível ou técnico, ela não subsiste sem ligações, sem se apegar aos objetos, às coisas" (LEFEBVRE, 2001, p. 54). Nesse ponto o autor faz uma distinção importante, ainda que tendenciosa, entre a cidade e o urbano, afirmando que este último parece ter sido concebido como entidade autônoma, exclusivamente especulativa, resultante de relações sociais constituídas unicamente pelo pensamento. $O$ autor apresenta outras definições da cidade, seja como "projeção da sociedade sobre um local", seja como "o conjunto das diferenças entre as cidades", ou, ainda, como "simultaneidade de padrões de vida urbana". Concluindo que se o fenômeno urbano é pensado sem a base prático-sensível, sem materialidade e morfologia adequada, tende a desaparecer.

Uma das definições mais concisas e elucidativas sobre cidade é dado por Park (1973), em seu texto sobre as perspectivas para o estudo da vida urbana: "um estado de espírito, um corpo de costumes e tradições e dos sentimentos e atitudes organizados, inerentes a esses costumes e transmitidos por essa tradição. Em outras palavras, a cidade não é meramente um mecanismo físico e uma construção artificial. Está envolvida nos processos vitais das pessoas que a compõem; é um produto da natureza, e particularmente da natureza humana" (PARK, 1973, p. 26).

Ao contrário de Lefebvre e Park, que consideram a cidade como obra transcendente das ações humanas sobre a natureza, Wirth (1973) sugere uma leitura técnica, regimental, quase matemática: "para fins sociológicos, uma cidade pode ser definida como um núcleo relativamente grande, denso e permanente, de indivíduos socialmente heterogêneos" (WIRTH, 1973, p. 96).

O foco da questão passa da influência do projeto urbano sobre o espaço público para a relação dialética entre a cidade e o urbano, dois conceitos opostos e complementares, que formam uma unidade, além das fragmentações analíticas, de acordo com Lefebvre (2001). Ao mesmo tempo em que a cidade prescinde do urbano - no sentido de dotar o espaço público de condições de planejamento, ordenamento e gestão do território - o urbano atua como mediador de políticas de controle do espaço público. De um modo resumido, podemos pensar que a cidade e o urbano são mediadores de forças antagônicas que disputam um mesmo território. Poderíamos pensar se a ideia de uma cidade compreendida atualmente como fragmentada, dispersa e conectada por infraestruturas que moldam o espaço urbano, permanece sendo a cidade que Lefebvre considerou "mediação entre as mediações". Será que a cidade permanece interface entre a ordem próxima, local da produção do cotidiano, e a ordem distante, absorvendo os impactos das estratégias de controle do espaço?

De um lado, os projetos urbanos podem ser entendidos como mediadores de relações de ordem próxima, indo além de soluções de natureza normativa, valorizando as identidades 
locais e as pré-existências. De outro lado, podem-se interpretar determinados projetos urbanos em territórios informais como instrumentos de "formalização" sócio-espacial.

Borja (2003) discute em seu livro "La ciudad conquistada" que os conceitos de cidade, espaço público e cidadania são partes de sistemas teóricos distintos, mas que se relacionam dialeticamente entre si. Em outras palavras, pode-se entender que certas antíteses relacionadas com estes conceitos não são necessariamente tratadas como antagonismos insuperáveis. $\mathrm{O}$ autor afirma ainda que "o espaço público é um conceito próprio do urbanismo que às vezes se confunde (erroneamente) com espaços verdes, equipamentos ou sistema viário, mas que também é usado em filosofia política como lugar de representação e de expressão coletiva da sociedade" (BORJA, 2003, p. 21). Sua obra difunde a ideia de que o espaço público constitui a essência da cidade, sendo também, por derivação, espaço político, de formação e experimentação de vontades coletivas, esperança de progresso e de revolução. Borja (2003) ainda afirma que a cidade é o resultado do ordenamento de espaços relacionais, muitas vezes representados em lugares significantes, que podem ser considerados arquétipos de cidades. Paraisópolis é, por assim dizer, uma representação arquetípica de uma cidade em processo. Trata-se de uma ideia de cidade que se desenvolveu originalmente de um plano frustrado de tornar-se um bairro de alta renda. Uma cidade que se faz lugar de rupturas institucionais, materiais, culturais, sociais, ambientais e econômicas - mas também é lugar de intercâmbio constante em meio a diversas escalas. Uma cidade que tem sido sitiada pela cidade que a envolve, por meio de infraestruturas de mobilidade urbana, saneamento, eletricidade, entre outras. O resultado de tais práticas de gestão urbana são ações executadas sob a condição explícita da melhoria da qualidade de vida e do desenvolvimento local, mas organizadas segundo funções implícitas de controle do território.

\section{PROJETO URBANO}

A intenção nessa parte do texto é recorrer a alguns fragmentos de discursos referentes a conceitos e noções fundamentais para o entendimento de certas ações que, de acordo com Secchi (2006), pensam o projeto como reinvenção do lugar. Paradoxalmente, tais projetos parecem deslocados da realidade concreta que propõem reinventar ao minimizar valores humanos diante de parâmetros de cunho tecnológico, como eficiência e economia, por exemplo. Desse modo, projeto seria uma resposta técnico-científica que consideraria meio ambiente, cultura e homem como conceitos desconexos. Nesse sentido, projetos urbanos poderiam ser analisados criticamente partindo de dois posicionamentos políticos opostos, mas complementares. De um lado, como mediadores de estratégias de controle do espaço público. De outro lado, como agenciadores do desenvolvimento local e de práticas de sustentabilidade ambiental.

Ao tratar do conceito de projeto urbano, talvez seja importante caracterizar e contextualizar o termo urbanização - entendido aqui como o conjunto de ações dirigidas para controle do espaço informal - no intuito de evitar confusões conceituais e programáticas. Para Topalov (2014) a noção de urbanização pode ser mais bem compreendida conhecendo-se a obra de Idelfonso de Cerdá, Teoria General de la Urbanización, publicada em 1867. Mesmo antes, Cerdá promoveu a ampliação da expressão latina para cidade (urbs, urbis) objetivando a descrição dos fenômenos sócio-espaciais mais complexos que transformaram as cidades desde meados do século XIX. De modo resumido, urbanização seria o ato de converter em cidade - 
urbs, urbis - espaços livres abertos, por meio da produção de infraestruturas. Topalov (2014) entende que há um sentido mais estrutural: "em princípio, urbanização designava, segundo Cerdá, um conjunto de procedimentos e métodos, além de uma doutrina, uma arte e uma ciência" (TOPALOV, 2014, p. 631). O termo "urbanização" poderia ser entendido, originalmente, como o conjunto de ações dirigidas para a produção de espaços urbanos incluindo as diversas funções conectadas com a realização social, material, política, econômica e cultural - de modo multiescalar, desde fragmentos de bairros até cidades inteiras.

Tal acepção pode parecer ambígua se for confrontada com as principais vertentes do urbanismo contemporâneo, como discutido por Lacaze (1993). Esse autor afirma que, enquanto planos de urbanização são grupos de estratégias mais complexo e abrangente do que o escopo de projetos urbanos, projetos designam "a conduta intelectual que permite propor uma realização, justificando de antemão, por um conjunto de planos e cálculos, a coerência do objeto a ser construído e sua adequação ao programa definido a princípio pelo arquiteto responsável pelo projeto" (LACAZE, 1993, p. 22).

Para Secchi (2006), projeto de cidade é um termo mais amplo que o de plano. Esse autor fala de projeto urbano na perspectiva da renovatio urbis. Nas suas palavras, "política de mudança e transformação do horizonte de sentido, do papel e das funções desenvolvidas por partes inteiras da cidade ou pela cidade toda, por meio de intervenções pontuais e limitadas, objetos finitos - não necessariamente edifícios - únicos e não repetíveis, tanto mais não fosse pela específica lógica de não poderem ser produzidos em série" (SECCHI, 2006, p. 124). Essa tarefa de modo algum significa uma tentativa de manutenção de formas definidas a priori, expressionistas ou anacrônicas. Pelo contrário, mantém relações muito articuladas com o projeto de cidade, com o plano urbanístico e com as políticas urbanas.

Os técnicos envolvidos com o projeto urbano, liderados por arquitetos e urbanistas, procuram reconstruir o lugar público, definindo diretrizes estratégicas em contextos de demandas imprecisas. Pode-se questionar quão estratégico é esse exercício de pensamento sobre possibilidades de articulação do espaço urbano e seu contexto social e político. Poderia haver, assim, um esforço de controle político dirigido contra a própria cidade contemporânea, reconhecidamente heterogênea, fragmentada, complexa e contraditória? A resposta a essa questão não é simples. Talvez o caminho seja considerar projeto urbano como componente de uma relação dialética entre práticas materiais, representacionais e simbólicas, como Secchi (2006) aborda de modo esclarecedor ao explicar os pontos de convergência e divergência entre plano urbanístico e projeto urbano.

Em relação aos projetos urbanos, o autor entende que, "não obstante seu valor intrínseco, muitos dos mais recentes projetos urbanos têm, no melhor dos casos, o caráter de um fragmento de um discurso sobre a cidade, quando não o caráter de 'exemplos exemplares' fora do tempo" (SECCHI, 2006, p. 127). Em contraposição, o plano urbanístico pode ser entendido como "conjunto de enunciados ao mesmo tempo teóricos e práticos, descritivos e institucionais, analíticos e regulamentares, composto de inferências e de decisões, de afirmações e de decretos" (SECCHI, 2006, p. 131). Trata-se da programação de ações coordenadas diacronicamente, gerenciadas por diversos agentes políticos, articuladas com demandas muitas vezes imprecisas, localizadas em contextos sócio-espaciais com alto grau de especificidade. No entanto, Secchi (2006) afirma que o projeto pode ser articulado em torno de dois eixos principais, sendo um organizado pela noção de escala, que não se limitaria à dimensão geográfica, social, política, econômica, e o outro orientado no sentido de explicitar as formas de linguagem, do implícito ao explícito. 
Ariella Masboungi (2002) apud Borja (2003) considera que o termo francês "projeto urbano" restringe-se ao modo de pensar estratégias de desenvolvimento territorial em alguns países europeus de origem latina, especialmente França. Itália e Espanha. Entre os objetivos principais pode-se incluir: função social da terra, atendimento a políticas de habitação social, possibilitar a implantação de políticas de sustentabilidade ambiental a nível local, proporcionar sistemas de espaços públicos de alta qualidade, orientação política eficaz na superação de dificuldades físicas, funcionais e sociais existentes na área urbana. Nesse sentido, Masboungi (2002) enfatiza três linhas de ação como conseqüência da práxis do projeto urbano. Em primeiro lugar, a orientação dos objetivos do projeto no sentido de uma abertura para o debate público. Em segundo lugar, a valorização das micro-utopias, de modo a inspirar os diversos agentes a agir em prol das transformações. E, finalmente, a capacidade de o projeto servir como mediador de conflitos entre a permanência das estruturas urbanas existentes e a flexibilidade necessária por uma sociedade em constante evolução.

LUGAR

A produção de lugar pode ser estudada por meio de duas dimensões de análise - a dimensão do discurso e da realidade concreta - articuladas com os conceitos de espaço, tempo e identidade, em diferentes abordagens de acordo com alguns campos do conhecimento especialmente os campos da geografia social, da psicologia ambiental, do projeto arquitetônico, do projeto urbano, da sociologia urbana e da antropologia. Para nosso estudo, de modo simplificado, lugar poderia ser conceituado como o produto das relações dialéticas entre as condições espaciais, as práticas sócio-culturais e as temporalidades do cotidiano.

\begin{abstract}
Uma premissa fundamental relacionada com o conceito de lugar é a de que nos relacionamos com o espaço e com os objetos dispostos no espaço, incluindo lugares, segundo padrões antropocêntricos: "em sentido literal, o corpo humano é a medida de direção, localização e distância" (TUAN, 1983, p. 50). A questão que se propõe aqui é que o espaço e a experiência sobre/no espaço estão relacionados com o sentido humano de competência e liberdade. Para Tuan (1983), humanização do espaço significa o conjunto de ações sociais materializadas na amplitude espacial, produzindo lugar. Em suas palavras, "os seres humanos necessitam de espaço e de lugar. As vidas humanas são um movimento dialético entre refúgio e aventura, dependência e liberdade" (TUAN, 1983, p. 61).
\end{abstract}

Uma das dimensões mais evidentes no conceito de lugar é a dimensão da identidade, que constitui parte essencial da noção de cidadania. Se cidadania pode ser entendida como expressão de desejo e necessidade diante de forças que atuam nos meios de produção onde prevalecem o controle e a exploração da sociedade, seria adequada a explicação de Gomes (2002) sobre o recuo da cidadania na cidade contemporânea. Esse processo de encolhimento sócio-espacial que o autor descreve pode ser evidenciado pelo modo como se multiplicam os espaços comuns - mas não públicos - de forma fragmentada e dispersa, sob o controle privatizado, direta ou indiretamente. Cidadania encontra-se no âmago de uma dinâmica que coloca em xeque a possibilidade de produção de lugar público, em um contexto de supressão de espaço público e de diversos direitos relacionados à conquista da cidade. Borja (2003) enumera alguns direitos vinculados ao direito à cidade, entre os quais podemos citar o direito à moradia e ao lugar, o direito ao espaço público e à monumentalidade, o direito à beleza, o 
direito à identidade coletiva dentro da cidade, o direito à mobilidade e à acessibilidade, entre muitos outros.

Augé (2003) afirma que o lugar antropológico tem pelo menos três características comuns. Podem ser ao mesmo tempo identitários, relacionais e históricos: "as regras da residência, os guardiões da aldeia, os altares, as praças públicas, os recortes das terras correspondem para cada um a um conjunto de possibilidades, prescrições e proibições cujo conteúdo é, ao mesmo tempo, espacial e social" (AUGÉ, 2003, p. 52). Desse modo, Augé (2003) define o lugar como o jogo de relações socioespaciais interdependentes que ocorrem no espaço, em oposição aos não lugares, definidos por fluxos, nos quais o tempo é a estrutura que articula as relações. Pode-se partir da premissa que evento é o resultado de relações humanas no espaço que implicam interações com humanos entre si e com não-humanos. De acordo com o pensamento de Certeau (1984), eventos seriam, assim, representações sociais do espaço vivido, no qual a forma social e a forma física seriam os modos de ação.

Gomes (2002) apresenta quatro processos que podem indicar o que ele denomina recuo do espaço público: "a apropriação privada crescente dos espaços comuns; a progressão das identidades territoriais; o emuralhamento da vida social; e o crescimento das ilhas utópicas" (Gomes, 2002, 176). O recuo da cidadania e do espaço público seriam, assim, efeitos colaterais das novas tecnologias de informação e comunicação na ampliação dos sistemas de vigilância, monitoramento e controle dos territórios urbanos.

\section{ATIVISMO URBANO: POR UMA PRODUÇÃO DEMOCRÁTICA DO ESPAÇO PÚBLICO}

O ativismo urbano e o valor de uso do espaço público. No entanto, na outra ponta dos movimentos pelo espaço público, o que muitos desses grupos ativistas parecem querer promover, segundo Wisnik (2015), é o acesso público e democrático a espaços mais bem qualificados e a serviços básicos de infraestrutura, como ônibus, trem e metrô.

$O$ interesse pelo espaço público fora das áreas centrais das cidades, em direção às áreas mais periféricas é um fenômeno relativamente novo. Alguns pesquisadores e agentes da administração pública entendem que o espaço público é particularmente um problema dos centros urbanos, e não da periferia, por se tratarem de locais emblemáticos, com grande diversidade de estruturas simbólicas e patrimônio edificado de valor histórico. Assim, moradores das periferias tornam-se construtores de novas áreas de uso público, atuando, através de usos cotidianos, sobre tecidos urbanos muitas vezes precários e fragmentados. Conseqüentemente, usam-se muito mais as ruas como espaço de convivência cotidiana, independentemente de uma definição tipológica formalista.

Falar do direito à cidade como síntese de diversos outros direitos passíveis de serem exercidos pela cidadania é fazer referência a teorias e práticas situadas no contexto dos movimentos culturais ativistas e de resistência estudantis que ocorreram nas metrópoles globais na década de 1960. Tais movimentos se opuseram a valores estabelecidos, com o objetivo tácito de se lançar no caminho da afirmação de novos valores, mais inclusivos e tolerantes à alteridade.

A partir dos anos 1960, diversos autores reafirmaram a importância do uso de métodos participativos de decisão na melhoria da qualidade de projetos de espaços públicos (ver, por exemplo, Lacaze (1981); Jacobs (2000); Rosa (2011); Brillembourg (2013); Alexander (2013); e Gehl (2013). A maioria desses autores citados acima defende que, apesar da capacidade técnica dos economistas, administradores, engenheiros, arquitetos e urbanistas, excelentes 
idéias podem vir dos usuários. Nesse sentido, idealmente, o papel do arquiteto se resume a representar e defender o que há de melhor para as pessoas que, mesmo sendo afetadas pelos projetos, normalmente não tomam parte no processo decisório.

Continuando o pensamento de Lefebvre (2006), no qual o direito à cidade depende de articulações entre a ordem próxima e a ordem distante, entre o local e o global, entre táticas e estratégias, entre as noções de cidadania e governo, entre o valor de uso e o valor de troca. Às projeções da ordem distante sobre a ordem próxima não correspondem reflexões nem transparências que possam ser facilmente identificadas como representações desse jogo de forças. Aqui há um deslocamento das premissas e objetivos de intervenções urbanas quando se pretendem adotar elementos de percepção ambiental como ferramentas de projeto. Del Rio (2002), em um texto sobre projeto e psicologia, afirma que projetos e intervenções estratégicas nas cidades devem ser precedidos de estudos ambientais dedicados às especificidades dos ambientes sobre o qual se pretende agir, objetivando compreender melhor as relações sociais, demandas e expectativas desses territórios urbanos. $\mathrm{O}$ autor, apoiado em teorias desenvolvidas principalmente por Edward Hall, Robert Sommer, Gordon Cullen, Kevin Lynch, Amos Rapoport e William Whyte, aborda uma temática ainda pouco explorada na práxis projetual atualmente, que estuda "as relações psicossociais entre o homem e o seu ambiente construído" (DEL RIO, 2002, p. 204).

Ao considerar que os atos de urbanismo podem ser profundamente desigualitários, como afirma Lacaze (1993), entende-se que fazer projeto ultrapassa a dimensão espacial e torna-se tridimensional, articulando espaço, tempo e indivíduo. O tempo intervém como elemento da evolução das cidades e como duração dos planos e projetos urbanos. Os homens intervêm duplamente, como sujeitos e atores das ações sobre a cidade. "não mais aceitam que o contexto de sua vida cotidiana seja transformado em função de lógicas que não lhes dizem respeito" (LACAZE, 1993, p. 25). Se projetos urbanos podem ser entendidos, concomitantemente, como mediadores de relações de ativação do desenvolvimento local e como instrumentos de "formalização" sócio-espacial, a serviço de interesses globais, o projeto colaborativo pode ser uma via de equilíbrio. Nesse ponto, a participação dos interessados mais próximos, os moradores locais, pode ser uma ferramenta projetual essencial para a produção de espaços públicos e a manutenção da qualidade ambiental em médio prazo.

Borja (2003) fala dos efeitos da globalização sobre o desenvolvimento local. Afirma que, apesar de ser hoje em dia um fato inconteste, as políticas descentralizadoras de governança têm se tornado prerrogativas de grupos privilegiados que visam à proteção de certas condições favoráveis de pequenas comunidades.

Concluindo, poderia se questionar o que é ativismo urbano hoje em dia. Pode-se dizer que o ativismo urbano de hoje tem sido apresentado como um conjunto de estratégias e táticas fundamentadas na participação popular inclusiva em todas as etapas de produção do espaço público. Muitas vezes a participação popular é organizada e assessorada por agentes do terceiro setor, especializados em relações interinstitucionais para o desenvolvimento local entre os quais podemos citar as associações, os coletivos, os comitês, as cooperativas, os institutos, os movimentos sociais, as ONGs, as OSCIPs, as redes, os fóruns, ou, ainda, os grupos de estudos sociais e urbanos. Nesse sentido, forças sociais e políticas são necessárias para entender que "a realização da sociedade urbana exige uma planificação orientada para as necessidades sociais" (Lefebvre, 2001, p. 138). Exemplos de práticas sociais com foco no espaço público originadas pelo desejo de cidadania de populações em condições de precariedade e escassez têm se multiplicado no mundo todo. No Brasil, podemos citar, por 
exemplo, o trabalho de Rosa (2011) em prol de um novo modo de produção do espaço público, que reflete em parte o paradigma do urbanismo do cotidiano, de acordo com o qual práticas sociais e apropriações coletivas, especialmente iniciativas populares - ações horizontalizadas, botton-up, em oposição a ações verticalizadas, top-down - alteram a configuração da paisagem urbana positivamente.

\section{PARAISÓPOLIS: DOIS PROJETOS URBANOS, DOIS “EXEMPLOS EXEMPLARES”}

\section{PARAISÓPOLIS: UMA CIDADE DENTRO DA OUTRA.}

O abandono dos lotes pelos proprietários originais foi ocasionado principalmente pela falta de infraestrutura - água, esgoto, arruamento, distribuição de energia elétrica. Esse descuido por parte dos empreendedores imobiliários e proprietários facilitou a ocupação por grileiros e posseiros, que se intensificou no final da década de 60 , quando as ruas foram oficializadas pela Lei no 7.180, de 17 de setembro de 1968. Como a legislação da época da implantação do novo bairro não exigia a doação de áreas verdes e institucionais nas glebas parceladas, as únicas áreas públicas do loteamento são aquelas constituídas pela malha viária ortogonal proposta. Segundo informações da Prefeitura Municipal de São Paulo, em 1968, foi contratado um Plano de Desenvolvimento Integrado, apontando a necessidade de desapropriação da área para fins de urbanização. Tal plano, no entanto, não foi efetivamente implantado. O Plano Diretor do Município de São Paulo, aprovado em 2002, instituiu as ZEIS - Zonas Especiais de Interesse Social - com o intuito de pensar estratégias de planejamento urbano de acordo com a realidade local de cada região administrativa, que passou a ser gerenciada por subprefeituras. Desse modo, foram demarcadas em Paraisópolis as ZEIS 1-W 045, W 046, W 047, W 048, W 050, e ZEIS 3 - W 001. Devido ao fato da ocupação ocorrer em área particular, foi publicado o Decreto Municipal no 42.871/03 de 19/02/2003, autorizando à HABI/SEHAB executar e implantar o Plano de Urbanização das ZEIS do Complexo Paraisópolis. No início de 2006, foram publicados os Decretos 47.144/06, autorizando o Poder Executivo a receber em doação, imóveis destinados ao Projeto Paraisópolis, concedendo o perdão da dívida de tributos, e 47.272/06, dispondo sobre a aplicação da transferência do direito de construir na hipótese de doação de imóveis destinados ao Projeto Paraisópolis.

Segundo o estudo de Almeida e D'Andrea (2004) sobre as redes de socialização em Paraisópolis, há uma grande carência de equipamentos de lazer e cultura, bem como ausência de áreas verdes e arborização urbana: "de modo geral, pode-se afirmar que as relações de convívio e lazer entre os moradores ocorrem nas ruas, becos e vielas. As crianças utilizam os córregos como áreas de lazer, enquanto os adultos utilizam bares, forrós e igrejas para terem um convívio social (ALMEIDA e D'ANDREA, 2004, p. 96).

O sistema de acessos em Paraisópolis tem como principal ligação o sentido Norte-Sul feito pela Rua Pasquale Gallup, apoiada pelas ruas Ernest Renam e Iratinga. O sentido Leste-Oeste cumpre o papel de vias de penetração e interligação com o sistema viário oficial: as ruas Melchior Giola, Herbert Spencer e Rudolf Lotze. O uso do solo é, predominantemente, residencial. Mas há, especialmente nas principais vias um uso misto entre comércio, serviços e residências.

O relevo é formado por planícies inundáveis circundadas por colinas suaves e cabeceiras de drenagem, que tem no trecho compreendido entre as ruas Melchior Giola, Pasquale Gallupi e 
Ernest Renan o principal divisor de águas. Em função da topografia local da área onde se insere a Favela de Paraisópolis, há quatro microbacias que conduzem as águas originárias da favela: Antonico, Brejo, Grotão e Grotinho. Suas características são semelhantes, tais como elevada densidade, pouca permeabilidade e declividades acentuadas. Em vários trechos dos fundos de vale, observa-se a existência de edificações construídas sobre cursos d'água, diminuindo a seção útil de escoamento e constituindo elemento de obstrução, de acúmulo de detritos e resíduos sólidos domésticos lançados inadvertidamente, acarretando inundações.

Foram contratados pela prefeitura, de acordo com PMSP (2012), diagnósticos urbanísticos ambientais, sócio-econômicos e fundiários do complexo Paraisópolis, realizados entre 2002 e 2005, pelas empresas Bureau, Diagonal Urbana, e Hagaplan, que subsidiaram os projetos e obras a partir de 2008. A quadro 1 apresenta a síntese do conjunto de infraestruturas existente em 2005, realizada pela empresa de consultoria e projetos Hagaplan, é apresentada abaixo.

Quadro 1: Infraestrutura existente em Paraisópolis, 2005.

\begin{tabular}{|l|l|l|l|l|l|}
\hline SETOR & $\begin{array}{l}\text { Total de } \\
\text { imóveis }\end{array}$ & $\begin{array}{l}\text { Percentual em } \\
\text { relação ao } \\
\text { total }\end{array}$ & $\begin{array}{l}\text { Abasteciment } \\
\text { o de água } \\
\text { oficial }\end{array}$ & $\begin{array}{l}\text { Coleta de } \\
\text { esgoto oficial }\end{array}$ & $\begin{array}{l}\text { Rede elétrica } \\
\text { oficial }\end{array}$ \\
\hline Antonico & 8.415 & $40,32 \%$ & $51,08 \%$ & $20,23 \%$ & $19,88 \%$ \\
\hline Brejo & 1.664 & $8,05 \%$ & $54,31 \%$ & $20,3 \%$ & $34,56 \%$ \\
\hline Centro & 1.880 & $9,01 \%$ & $55,51 \%$ & $29,72 \%$ & $31,11 \%$ \\
\hline Grotão & 3.173 & $15,21 \%$ & $63,98 \%$ & $7,18 \%$ & $8,08 \%$ \\
\hline Grotinho & 2.009 & $9,63 \%$ & $24,26 \%$ & $4,55 \%$ & $4,55 \%$ \\
\hline Jd. Colombo & 3.226 & $15,55 \%$ & $58,93 \%$ & $14,96 \%$ & $14,57 \%$ \\
\hline Porto Seguro & 465 & $2,23 \%$ & $57,11 \%$ & $9,64 \%$ & $40,72 \%$ \\
\hline TOTAL & 20.832 & $100,0 \%$ & & & \\
\hline
\end{tabular}

Fonte: adaptado de Hagaplan/Sondotécnica/Prefeitura Municipal de São Paulo.

Em 2004 o consórcio de empresas de consultoria HAGAPLAN/Sondotécnica foi contratado, com o apoio da Prefeitura Municipal de São Paulo, para elaboração de Plano e Projeto de Urbanização do Complexo Paraisópolis. O escopo dos serviços incluiu a realização de: Levantamentos Básicos e Diagnósticos; Estudos de Alternativas; Projeto Básico - incluindo as áreas de Urbanismo, Sistema Viário, Sistema de Água, Sistema de Esgoto, Sistema de Drenagem, Consolidação Geotécnica; e, ainda, Planos de Urbanização das ZEIS.

Segundo informações da Prefeitura Municipal de São Paulo, o Projeto Paraisópolis contemplava a participação da população moradora local e do entorno, bem como o apoio de entidades na implantação das ações por meio dos Conselhos Gestores das comunidades de Paraisópolis, Jardim Colombo e Porto Seguro. De acordo com PMSP (2012), os Planos de Urbanização das ZEIS 1 W 045, W 046, W 047, W 048, W 050 e ZEIS 3 W 001 foram aprovados pelos respectivos Conselhos Gestores e posteriormente aprovados através dos decretos municipais 46.018/05, 46.117/05 e 46.345/05. Foi elaborado um mapa de intervenções, apresentado abaixo. 
Quadro 2: Projetos Urbanos desenvolvidos para Paraisópolis (2001-2015). Fonte: Elaborado pelo autor.

\begin{tabular}{|c|c|c|c|c|}
\hline \multicolumn{5}{|c|}{ Projetos Urbanos em Paraisópolis } \\
\hline Ano & Título & Autoria & Descrição / Uso & Localização \\
\hline $2008-2012$ & $\begin{array}{c}\text { Grotinho Dois. CRAS - } 1 \\
\text { unidade. }\end{array}$ & \begin{tabular}{|c|} 
Boldarini Arquitetos \\
Associados \\
\end{tabular} & $\begin{array}{l}\text { Edifício Multiuso: CRAS. Uso } \\
\text { Comercial e Residencial. }\end{array}$ & Grotinho \\
\hline 2014 & $\begin{array}{l}\text { Centro de Triagem e } \\
\text { Ecoponto. }\end{array}$ & Libeskind \& Llovet & Reciclagem de resíduos sólidos. & Brejo \\
\hline 2014 & Pavilhão Social & $\begin{array}{c}\text { Ciro Pirondi \& Ruben } \\
\text { Otero } \\
\end{array}$ & Espaço Multiuso. & Grotão \\
\hline 2015 & Grotinho 3 & Suzel Maciel & Parque de Lazer do Grotinho 1 e 3 & Grotinho \\
\hline 2014 & \begin{tabular}{|c|}
$\begin{array}{c}\text { Projeto de Urbanização do } \\
\text { Córrego do Antonico }\end{array}$ \\
\end{tabular} & MMBB Arquitetos & \begin{tabular}{|c|} 
Projeto urbano envolvendo \\
saneamento básico e cursos d'água.
\end{tabular} & Antonico \\
\hline 2012 & $\begin{array}{l}\text { Urbanização do Porto } \\
\text { Seguro e infraestrutura. }\end{array}$ & \begin{tabular}{|c|}
$\begin{array}{c}\text { Prefeitura Municipal } \\
\text { de São Paulo. }\end{array}$ \\
\end{tabular} & $\begin{array}{l}\text { Projeto de mobilidade e vias } \\
\text { públicas. }\end{array}$ & Porto Seguro \\
\hline 2010 & $\begin{array}{c}\text { Urbanização do Grotinho e } \\
\text { infraestrutura }\end{array}$ & $\begin{array}{l}\text { Prefeitura Municipal } \\
\text { de São Paulo. }\end{array}$ & $\begin{array}{l}\text { Projeto de mobilidade e vias } \\
\text { públicas. }\end{array}$ & Grotinho \\
\hline 2012 & $\begin{array}{c}\text { Urbanização do Antonico e } \\
\text { infraestrutura }\end{array}$ & \begin{tabular}{|c|}
$\begin{array}{c}\text { Prefeitura Municipal } \\
\text { de São Paulo. }\end{array}$ \\
\end{tabular} & \begin{tabular}{|c|} 
Projeto urbano envolvendo \\
saneamento básico e cursos d'água.
\end{tabular} & Antonico \\
\hline 2013 & $\begin{array}{c}\begin{array}{c}\text { Parque Linear do Córrego } \\
\text { do Antonico }\end{array} \\
\end{array}$ & \begin{tabular}{|c|}
$\begin{array}{c}\text { Prefeitura Municipal } \\
\text { de São Paulo. }\end{array}$ \\
\end{tabular} & Parque urbano. & Antonico \\
\hline 2012 & Parque Sanfona & $\begin{array}{l}\text { Prefeitura Municipal } \\
\text { de São Paulo. }\end{array}$ & Parque urbano. & Grotão \\
\hline 2013 & $\begin{array}{l}\text { TELECENTRO - } \\
\text { Condomínio E. }\end{array}$ & $\begin{array}{l}\text { Prefeitura Municipal } \\
\text { de São Paulo. }\end{array}$ & $\begin{array}{l}\text { Ensino e prática de novas } \\
\text { tecnologias de informação e } \\
\text { comunicação. }\end{array}$ & Condomínio E. \\
\hline 2013 & $\begin{array}{c}\text { Equipamentos saúde UBS / } \\
\text { AMA / CAPS. }\end{array}$ & $\begin{array}{l}\text { Prefeitura Municipal } \\
\text { de São Paulo. }\end{array}$ & Equipamentos de saúde. & Brejo \\
\hline 2012 & $\begin{array}{c}\text { Canalização do Córrego } \\
\text { Colombo. Parque Linear; } \\
\text { Urbanização do Colombo e } \\
\text { infraestrutura. }\end{array}$ & $\begin{array}{l}\text { Prefeitura Municipal } \\
\text { de São Paulo. }\end{array}$ & Parque urbano. & Jardim Colombo \\
\hline $2004-2005$ & $\begin{array}{c}\text { Reurbanização do } \\
\text { Complexo Paraisópolis. }\end{array}$ & Viglieca e Associados & Projeto de Habitação Social. & Centro \\
\hline 2008 & $\begin{array}{c}120 \text { INCREMENTAL } \\
\text { HOUSING. }\end{array}$ & Elemental. Aravena. & Projeto de Habitação Social. & \\
\hline $2009-2010$ & Escola de Música & Urban-Think Tank. & $\begin{array}{l}\text { Edifício da Escola da Música e } \\
\text { Dança; } \\
\text { Área do entorno do Edifício } \\
\text { (urbanismo). }\end{array}$ & Grotão \\
\hline $2008-2009$ & $\begin{array}{l}\text { Programa Habitacional } \\
\text { Paraisópolis. } \\
\end{array}$ & Elito Arquitetos & Projeto de Habitação Social. & Brejo \\
\hline 2014 & Parque do Skate & Robert de Paauw & Lazer e Esporte. & Grotão \\
\hline 2009 & $\begin{array}{l}\text { São Paulo Architecture } \\
\text { Experiment. }\end{array}$ & $\begin{array}{l}\text { Urban-Think Tank. } \\
\text { SEHAB-SP. }\end{array}$ & Projetos de Infraestruturas. & $\begin{array}{l}\text { Grotinho, Brejo, } \\
\text { Centro, Grotão. }\end{array}$ \\
\hline
\end{tabular}




\section{URBAN THINK TANK. ESCOLA DE MÚSICA, 2010}

No ano de 2012, escritório Urban Think Tank venceu a categoria principal da etapa sulamericana do Holcim Awards, concurso trienal que destaca os melhores projetos de sustentabilidade do mundo. O projeto para uma escola de música localizada no Grotão, no coração da favela de Paraisópolis, em São Paulo foi liderado pelo arquiteto Alfredo Brillembourg. De acordo com Brillembourg (2010), localizado em um ponto emblemático da favela de Paraisópolis, conhecido como Grotão, tem dois objetivos principais: estabilizar a erosão e evitar os deslizamentos de terra, além de oferecer um espaço público e multifuncional altamente qualificado à comunidade.

A proposta envolveu participação intensiva da comunidade, como afirma arquiteto, objetivando decisões sobre a construção, a manutenção e a gestão do espaço de forma participativa e democrática. Assim, a participação efetiva da Associação de Moradores de Paraisópolis, organização que existe há mais de 30 anos, foi determinante em todas as etapas do processo.

Trata-se, na verdade de uma estrutura que poderia ser entendida como o resultado de uma linguagem de padrões, no sentido abordado por Alexander (2013), indicando cinco atributos conceituais que podem ser aplicados em uma análise tectônica do conjunto edificado e de seus componentes construtivos e tecnológicos: padrões éticos e de equidade social; qualidade ambiental e eficiência energética e de recursos naturais; impacto estético e marco contextual; compatibilidade e desempenho econômico; e, finalmente, possibilidade de servir como exemplo de boas práticas de projeto, podendo ser replicado em situações similares no Brasil e no mundo.

Além de uma quadra poliesportiva, uma sala para ensaios, quatro salas de aula e um auditório para até 300 pessoas, o edifício contempla outros elementos de projeto. Entre eles, um elevador público, com acesso a diversos pontos do projeto; acesso de ônibus; rotas acessíveis por rampas; sistema de estabilização do solo por meio de terraços; canteiros de agricultura urbana; playground; teatro de arena; adequação de vielas e becos existentes para conexão com os terraços e integração com o projeto; proposta de centro comunitário auxiliar. Além disso, como diz o arquiteto principal do projeto,

[...] diversas características de baixa tecnologia são propostas: um sistema de gerenciamento de água, para o reuso de água de chuva no local e o reaproveitamento de água cinzenta; e sistema integrativo para o uso ativo e passivo da ventilação, do resfriamento e do ar condicionado tanto na construção do edifício como na do anfiteatro (BRILLEMBOURG, 2010). 
ELEMENTAL. PROJETO PARA 120 MORADIAS, 2010.

A ideia de levar para a realidade da favela um nível de habitabilidade supostamente próprio da classe média foi uma das premissas do escritório chileno Elemental para pensar um conjunto habitacional em Paraisópolis. Nas palavras de Aravena (2010), isso é fundamental para que a habitação se transforme em investimento e deixe de ser gasto social. $O$ arquiteto elenca, assim, cinco atributos estruturais: "localização; projeto do conjunto urbano; $50 \%$ de frente para o lote urbano; estrutura para os 80 metros finais, não para os 40 metros iniciais; DNA de classe média nas partes mais complexas da casa banheiro, cozinha e escada" (ARAVENA, 2010, p. 86). Desse modo, com a meta de abrigar 150 famílias, bem como incluir uso comercial no térreo, foram projetados quatro blocos de oito andares, em terreno relativamente compacto com forte declive.

Apesar de mudanças para adequação à legislação brasileira, diminuindo para quase nada a porcentagem de autoconstrução, o Elemental aplicou suas premissas em conjunto com a ideia da meia casa com qualidade espacial e construtiva acima da média dos conjuntos habitacionais populares. Produzir meia casa de boa qualidade ao invés de construir uma casa inteira de qualidade inferior é a ideia central do Elemental. Diante da questão sobre qual metade fazer, a resposta: "a metade que uma família nunca vai fazer bem" (ARAVENA, 2010, p. 86).

Aravena (2010) entende que alguns setores vêem isso como uma filosofia antiautoritária, mas afirma que o Elemental defende a construção feita pelos moradores por uma razão pragmática. Antes vista como uma condição restritiva, a escassez torna-se uma estratégia de projeto dos arquitetos envolvidos nessa empreitada que valoriza a personalização e a customização das habitações pelos moradores. O fato é que, para o Elemental

[...] essa ideia de personalização pode ser aplicada às construções pré-fabricadas, que é a melhor maneira de fazer habitação social. A crítica que se fazia é que o pré-fabricado deixava tudo monótono e repetitivo. Quando vou fazer só a metade de uma casa, quando mais repetitivo e monótono eu for, o crescimento será incerto. Se junta uma questão filosófica com outra pragmática e uma econômica. É socialmente desejável, economicamente eficiente e politicamente correto. Quando a família constrói a sua parte, ela terá mais responsabilidade pelo imóvel (ARAVENA, 2010, p. 85).

Aravena (2010) considera que o Elemental procurou, desde o início, articular conhecimento específico com problemas indefinidos e abrangentes. Simplificando, problemas que interessam à sociedade em geral, em que é possível a participação de muitos, sejam economistas, políticos ou, ainda, a senhora que não sabe ler nem escrever. Desse modo, um comitê da periferia pode opinar tanto quanto um especialista. Trata-se do uso estratégico de conhecimentos específicos de projeto, para tratar de problemas inespecíficos e emergentes. 
Duas questões fundamentais: Em que medida seria possível medir/antecipar/dialogar/pensar em nível de projeto soluções ambientais amparadas por atributos/valores/categorias pertinentes ao uso de espaços públicos.

Quais elementos/constituintes de projetos urbanos poderiam ser mais bem ajustados no sentido de atender às demandas dos moradores/usuários/interessados?

$\mathrm{Na}$ tentativa de responder às questões acima, propõem-se duas etapas:

Estabelecimento de uma revisão teórica e conceitual que possa incluir e definir o que sejam os pares a seguir: projeto urbano/urbanização, espaço público/cidade, identidade/cidadania.

Análise crítica de dois projetos, não construídos, em dois terrenos localizados em Paraisópolis. Elemental e UTT.

O quadro pode sugerir uma abordagem diagramática. Um diagrama interpretativo.

Discussão dos resultados. Indicar as condições que favorecem a apropriação dos espaços públicos relacionados com determinados projetos urbanos.

Quadro 3: Fatores de impacto de projetos urbanos no desenvolvimento local. Dois casos em Paraisópolis.

\begin{tabular}{|c|c|c|c|c|}
\hline & $\begin{array}{l}\text { Espacialidade: } \\
\text { Demandas por espaço } \\
\text { público e recursos } \\
\text { locais. }\end{array}$ & $\begin{array}{l}\text { Temporalidade. } \\
\text { Respeito às pré- } \\
\text { existências. Tempo do } \\
\text { projeto. }\end{array}$ & $\begin{array}{l}\text { Identidade. } \\
\text { Participação popular } \\
\text { democrática. } \\
\text { Territorialidade. }\end{array}$ & $\begin{array}{l}\text { Discurso do projeto. } \\
\text { Articulação de ações } \\
\text { dentro de uma rede } \\
\text { sociotécnica local. }\end{array}$ \\
\hline Elemental & $\begin{array}{l}\text { O projeto atende e } \\
\text { ultrapassa as } \\
\text { expectativas diante das } \\
\text { necessidades locais e } \\
\text { das restrições } \\
\text { orçamentárias, legais e } \\
\text { políticas. }\end{array}$ & $\begin{array}{l}\text { Não parece haver } \\
\text { preocupação explícita } \\
\text { no ajuste dos arranjos } \\
\text { entre os edifícios } \\
\text { projetados e a } \\
\text { morfologia urbana da } \\
\text { favela. }\end{array}$ & \begin{tabular}{|l|} 
Há ênfase na \\
participação popular \\
nas principais etapas de \\
projeto, desde a \\
escolha do terreno até \\
os revestimentos e \\
detalhes construtivos. \\
Além disso, um dos \\
conceitos do projeto é \\
fortemente identitário, \\
no sentido de prever a \\
complementação das \\
habitações pelos \\
moradores.
\end{tabular} & $\begin{array}{l}\text { O grupo Elemental tem } \\
\text { discutido, ao longo de } \\
\text { diversas publicações e } \\
\text { projetos desenvolvidos } \\
\text { no mundo todo, sobre } \\
\text { o novo papel dos } \\
\text { arquitetos e urbanistas } \\
\text { na melhoria da } \\
\text { qualidade de vida das } \\
\text { populações mais } \\
\text { pobres. }\end{array}$ \\
\hline Urban Think Tank & $\begin{array}{l}\text { O projeto explora as } \\
\text { demandas por espaços } \\
\text { públicos e o apelo } \\
\text { popular pela } \\
\text { construção de uma } \\
\text { escola de música. }\end{array}$ & $\begin{array}{l}\text { O aproveitamento de } \\
\text { condições extremas de } \\
\text { ocupação, respeitando } \\
\text { as pré-existências é um } \\
\text { dos pontos fortes da } \\
\text { proposta. Além disso, } \\
\text { há a possibilidade da } \\
\text { integração com outras } \\
\text { ações e projetos ao } \\
\text { longo da implantação. }\end{array}$ & \begin{tabular}{|l|} 
A participação popular \\
teve um aspecto \\
deliberativo, mas não \\
tratou de questões de \\
pensamento de \\
projeto. A região \\
escolhida não é uma \\
centralidade, mais \\
permite visibilidade das \\
ações. Há muitas \\
questões sociais nessa \\
localidade que não \\
foram abordadas no \\
discurso do projeto. \\
\end{tabular} & $\begin{array}{l}\text { O UTT se dedica ao } \\
\text { estudo das soluções de } \\
\text { projeto em contextos } \\
\text { de escassez ao redor do } \\
\text { mundo. Apesar de } \\
\text { propor ações de certo } \\
\text { modo utópicas, tem } \\
\text { forte impacto nas redes } \\
\text { sociotécnicas a nível } \\
\text { local e global. }\end{array}$ \\
\hline
\end{tabular}

Fonte: Elaborado pelo autor. 
Quadro 4: Comparativo dos conceitos apresentados nos projetos urbanos desenvolvidos para Paraisópolis por Elemental e Urban Think Tank.

\begin{tabular}{|c|c|c|c|c|c|}
\hline & $\begin{array}{l}\text { Principais Ferramentas } \\
\text { de Projeto }\end{array}$ & \begin{tabular}{|l|} 
Participação \\
Popular \\
Deliberativa \\
Alta/Média/Baixa
\end{tabular} & $\begin{array}{l}\text { Restrições } \\
\text { Políticas / } \\
\text { Econômicas / } \\
\text { Sociais } \\
\text { Alta/Média/Baixa }\end{array}$ & $\begin{array}{l}\text { Demandas } \\
\text { Relacionais } \\
\text { Sociotécnicas } \\
\text { Alta/Média/Baixa }\end{array}$ & Ações / Usos / Funções \\
\hline \multirow{5}{*}{ Elemental } & Localização privilegiada & Alta & Alta & Alta & $\begin{array}{l}\text { Permite mobilidade a } \\
\text { um custo menor. } \\
\text { Valorização do imóvel. }\end{array}$ \\
\hline & \begin{tabular}{|l|} 
Projeto do conjunto \\
urbano
\end{tabular} & Média & Alta & Alta & $\begin{array}{l}\text { Integração uso privado } \\
\text { e uso público }\end{array}$ \\
\hline & $\begin{array}{l}50 \% \text { de frente para o } \\
\text { lote urbano }\end{array}$ & Baixa & Baixa & Baixa & $\begin{array}{l}\text { Expansão. Liberdade. } \\
\text { Aproveitamento } \\
\text { eficiente do espaço. }\end{array}$ \\
\hline & $\begin{array}{l}\text { Estrutura para os } 80 \\
\text { metros finais, não para } \\
\text { os } 40 \text { metros iniciais } \\
\end{array}$ & Baixa & Alta & Alta & $\begin{array}{l}\text { Coerência estrutural. } \\
\text { Durabilidade. } \\
\text { Resiliência. }\end{array}$ \\
\hline & $\begin{array}{l}\text { DNA de classe média } \\
\text { nas partes mais } \\
\text { complexas da casa } \\
\text { banheiro, cozinha e } \\
\text { escada } \\
\end{array}$ & Alta & Alta & Média & $\begin{array}{l}\text { Poder de escolha dos } \\
\text { moradores. Valorização } \\
\text { do imóvel. Resiliência. }\end{array}$ \\
\hline \multirow{5}{*}{$\begin{array}{l}\text { Urban Think } \\
\text { Tank }\end{array}$} & $\begin{array}{l}\text { Padrões éticos e de } \\
\text { equidade social }\end{array}$ & Média & Alta & Alta & $\begin{array}{l}\text { Promoção de ação } \\
\text { social através da } \\
\text { música. Uso misto. Uso } \\
\text { durante o dia todo, } \\
\text { todos os dias. }\end{array}$ \\
\hline & $\begin{array}{l}\text { Qualidade ambiental e } \\
\text { eficiência energética e } \\
\text { de recursos naturais } \\
\end{array}$ & Baixa & Alta & Média & $\begin{array}{l}\text { Capacidade de } \\
\text { manutenção. } \\
\text { Economia. }\end{array}$ \\
\hline & $\begin{array}{l}\text { Impacto estético e } \\
\text { marco contextual }\end{array}$ & Alta & Baixa & Alta & $\begin{array}{l}\text { Visibilidade. } \\
\text { Atratividade. } \\
\text { Divulgação. }\end{array}$ \\
\hline & $\begin{array}{l}\text { Compatibilidade e } \\
\text { desempenho } \\
\text { econômico } \\
\end{array}$ & Alta & Alta & Alta & $\begin{array}{l}\text { Adequação às } \\
\text { condições locais de } \\
\text { escassez. }\end{array}$ \\
\hline & \begin{tabular}{|l|} 
Possibilidade de servir \\
como exemplo de boas \\
práticas de projeto
\end{tabular} & Baixa & Alta & Alta & $\begin{array}{l}\text { Multiplicação. Modelo. } \\
\text { Replicabilidade. }\end{array}$ \\
\hline
\end{tabular}

Fonte: Elaborado pelo autor

\section{CONCLUSÃO}

Este trabalho dedicou-se à problematização do papel dos projetos urbanos nas articulações entre espaços públicos e a produção de lugar em favelas. A partir de duas perspectivas antagônicas, procurou-se identificar os elementos-chave que caracterizariam as intervenções urbanas, no sentido de indicar as condições que favorecem a apropriação dos espaços públicos resultantes. De um lado, os projetos urbanos podem ser entendidos como mediadores de relações de ordem próxima, indo além de soluções normativas, valorizando as identidades locais e as pré-existências. De outro lado, podem-se interpretar determinados projetos urbanos em territórios informais como instrumentos de "formalização" sócio-espacial. 
Após a análise de dois projetos reconhecidamente exemplares, pode-se afirmar que o ponto mais positivo dessas ações é o seu potencial como multiplicadores de práticas de desenvolvimento local, com forte apelo teórico e conceitual. No entanto, ainda é necessário aprofundar a pesquisa sobre os motivos de projetos urbanos de menor escala serem efetivamente implantados em Paraisópolis com a participação popular, seguindo os exemplos dos projetos emblemáticos abordados nesse texto.

\section{REFERÊNCIAS}

Alexander, Christopher. Uma linguagem de padrões. Porto Alegre: Bookman, 2013.

ALMEIDA, Ronaldo de; D'ANDREA, Tiaraju. Pobreza e redes sociais em uma favela paulistana. Novos Estudos - CEBRAP. 2004, n.68, pp.94-106.

ARAVENA, Alejandro. Paraisópolis. Projeto de 120 moradias. In: A cidade informal no século XXI. Catálogo de Exposição. São Paulo: MCB, 2010.

AUGÉ, Marc. Não-lugares: introdução a uma antropologia da supermodernidade. Campinas: Papirus, 2003.

BORJA, Jordi. La ciudad conquistada. Madri: Alianza Editorial, 2003.

BRILLEMBOURG, Alfredo. Grotão, Paraisópolis. In: A cidade informal no século XXI. Catálogo de Exposição. São Paulo: MCB, 2010.

DEL RIO, Vicente; DUARTE, Cristiane Rose; RHEINGANTZ, Paulo Afonso. Projeto do lugar: colaboração entre psicologia, arquitetura e urbanismo. Rio de Janeiro: Contra Capa / PROARQ, 2002.

JACOBS, Jane. Morte e Vida nas Grandes Cidades. São Paulo: Martins Fontes, 2000.

LACAZE, Jean Paul. Os métodos do urbanismo. Campinas, SP: Papirus, 1993.

LEFEBVRE, Henri. O direito à cidade. São Paulo: Centauro, 2001.

PARK, Robert Ezra. A cidade: sugestões para a investigação do comportamento humano no meio urbano. In: VELHO, Otavio Guilherme (Org.). O fenômeno urbano. Rio de Janeiro: Zahar, 1973, p. 26 67.

Prefeitura do Município de São Paulo. Plano Diretor Estratégico. LEI № 13.430, DE 13 DE SETEMBRO DE 2002.

ROSA, Marcos L. (Org.). Micro Planejamento: práticas urbanas criativas = Microplanning : urban creative practices. São Paulo: Editora de Cultura, 2011.

SECCHI, Bernardo. Primeira lição de urbanismo. São Paulo: Perspectiva, 2006.

TUAN, YI-Fu. Espaço e lugar: a perspectiva da experiência. São Paulo: DIFEL, 1983.

VELHO, Otavio Guilherme. (Org.). O fenômeno urbano. Rio de Janeiro: Zahar, 1973.

WIRTH, Louis. O urbanismo como modo de vida. In: VELHO, Otavio Guilherme (Org.). O fenômeno urbano. Rio de Janeiro: Zahar, 1973, p. 90 - 113. 
